\title{
Rice Yield Prediction Using MODIS - NDVI (MOD13Q1) and Land Based Observations
}

\author{
K. Ajith ${ }^{1 *}$, V. Geethalakshmi ${ }^{2}$, K.P. Ragunath $^{3}$, S. Pazhanivelan ${ }^{3}$ and Ga. Dheebakaran ${ }^{1}$ \\ ${ }^{1}$ Agro Climate Research Centre, TNAU, Coimbatore, Tamil Nadu, India \\ ${ }^{2}$ Department of Agronomy, AC \& RI, Madurai, Tamil Nadu, India \\ ${ }^{3}$ Department of Remote Sensing \& GIS, TNAU, Coimbatore, Tamil Nadu, India \\ *Corresponding author
}

\section{Keywords \\ Rice, Yield, Land based on observations. \\ Article Info \\ Accepted: \\ 17 October 2017 \\ Available Online: \\ 10 December 2017}

\section{A B S T R A C T}

Reliable yield forecasting within the growing season would enable better planning and more efficient management of grain production, handling and marketing. Remote sensing provides essential technologies for monitoring and observing rice fields over large areas at repeated time intervals. In this study MODIS- NDVI (MOD13Q1) 16 day composite with a spatial resolution of $250 \mathrm{~m}$ was used for establishing a relationship with rice yield by empirical method. The analysis was conducted for two seasons viz. Samba rice season of 2015-16 and 2016-17 of Thanjavur district. Multi-temporal MODIS- NDVI images in these two seasons were downloaded and pre-processed including re-projection, file type conversion, extraction etc. The result revealed that best relationship form between NDVI and rice age by fitting a quadratic equation. Out of the 28 locations under study, in 24 locations the $\mathrm{R}^{2}$ values for these equations showed fairly higher values ranging from 0.724 to 0.968 . Among the three parameters evaluated in this study, summation of the rice NDVI during observation ( $\sum \mathrm{NDVI}$ ) showed the highest exponential relationship with the rice yield. Rice yield prediction for Samba rice during 2016- 2017 was done based on the relationship developed between yield and $\Sigma$ NDVI, derived during 2015-16, i.e. $\mathrm{y}=$ $1903.6 \mathrm{e}^{0.0201 x}\left(\mathrm{R}^{2}=0.7495\right)$. The predicted Samba rice yield during 2016-17 was compared with the actual yields obtained through crop cutting experiments and out of the ten blocks under study 5 blocks had PBIAS values less than \pm 10 which indicated the good agreement between actual and predicted yield.

\section{Introduction}

Rice is the staple food for more than three billion people worldwide. Rice area accounted for approximately $11.5 \%$ of the world's arable land area and it provides almost $19 \%$ of the global dietary energy in recent times and its annual average consumption per capita was about $65 \mathrm{~kg}$. Therefore, rice area mapping and forecasting its production is vital for food security, where demands often exceed production due to an ever-increasing population. The aim of yield forecast is to give a precise, scientifically sound and independent forecasts of crops' yield as early as possible during the crops' growing season by considering the effect of the weather and climate (Basso, 2013). Timely and accurate estimation of rice areas and forecasting its production can provide important information for governments, planners, and decision makers in formulating 
policies with regard to import or export and in the event of shortfall or surplus (Mostafa, 2015). Different techniques are being employed for estimating crop yield viz. field data collection, agrometeorological tools, crop simulation models, remote sensing etc.

Early warning systems on expected crop production are being issued by every country at different lead times worldwide combining different approaches (IGOL, 2006). In a country like India where the agricultural production is more likely to be influenced by the vagaries of monsoon, crop area and production statistics are of vital importance. The traditional approach of crop estimation in India involves a complete enumeration based on crop cutting experiments for estimating crop acreages and yield. The crop production assessments are obtained by taking products of crop acreage estimates and corresponding crop yield estimates. Such techniques are often subjective, costly and are prone to large errors, leading to poor crop assessment and crop area estimation (Reynolds et al., 2000). Also, the collected data may become available too late for appropriate action to be taken to ward off food shortage. At the same time, no yield prediction model, unless developed or tested locally are suitable for local use due to variability in soil attributes, climatic conditions, plant species varieties and agricultural practices from one area to another (Shresthan and Naikaset, 2003). Hence, there is a need to reduce the cost and also to improve upon the accuracy and time of crop yield prediction before harvest (Misra and Shrivastava, 1998).

Remote sensing can obtain surface information macroscopically, periodically and economically. It has many advantages in agricultural monitoring and survey. Governments has long been paid much attention to survey crop acreage and yield using remote sensing, and great success has been achieved (Narasimhan and Chandra, 2000; Dadhwal and Ray, 2000; Bastiaanssen and Ali, 2003; Prasad et al., 2006). These methods are generally based on empirical / statistical models that needed to be performed on continuing basis and for different agroclimatic zones due to changing environmental conditions and cultivars at different locations (Noureldin, et al., 2013; Wang, 2010). Normalized Difference Vegetation Index (NDVI) is one of the best indicating factors of the vegetative growth condition and the degree of vegetative cover (Banair et al., 1995). If an area is covered by vegetation, then the NDVI value of that area is just a positive number, and increases along with the increase in vegetative cover (Zhao, 2001). In recent years, the focus of remote sensingbased yield forecasting research has shifted to the National Aeronautics and Space Administration's (NASA) Moderate Resolution Imaging Spectroradiometer (MODIS), which provides improved radiometric calibration and superior spectral and spatial resolution relative to the Advance Very High Resolution Radiometer (AVHRR) (Becker-Reshef et al., 2010). It is therefore important to investigate the possibilities of employing widely available datasets such as MODIS- NDVI for yield prediction.

Several researchers have done works exploring and assessing utility of open source MODIS-NDVI. The NDVI data derived from the AVHHR of the National Oceanic and Atmospheric Administration (NOAA) have been used extensively to monitor crop condition and forecasting yield and subsequently production in many countries as reported by Mkhabela (2011). He also studied the potential of using MODIS-NDVI to forecast crop yield on the Canadian Prairies and also to identify the suitable time for making a reliable crop yield forecast. Results showed that MODIS-NDVI data can be used effectively to predict crop yield on the 
Canadian Prairies. Kouadio et al., (2014) developed regression models using agroclimate, MODIS-NDVI and MODIS-EVI (Enhanced Vegetative Index) as input for the in-season yield forecasting of spring wheat during the 2000-2010 period. The mean absolute error percentages of the models selected from both the two data sets ranged from $2 \%$ to $33 \%$ over the study period. Lopresti, (2015), calibrated and validated an empirical model with field-observed wheat yields and (MOD13Q1) NDVI product data, in the North of Buenos Aires province, Argentina. At department level, an $\mathrm{R}^{2}$ value of 0.75 was found after relating the estimation of the calibrated empirical model with official yields. Mahboob et al., (2016) has carried out a study to estimate the area and to forecast yield of rice crop using satellite imagery in the Sylhet region of Bangladesh using Terra and Aqua MODIS-derived 8-day composite of NDVI at $250 \mathrm{~m}$ spatial resolution in conjunction with ancillary datasets during the period of 2002-2012. The correlation coefficient (r) between production and maximum NDVI has been found as 0.707 and 0.837 for Boro and Aman rice respectively. In this paper methods for predicting regional rice yield using MODIS-NDVI is explored. The objective of the study is to evaluate the potential of MODIS-NDVI in rice yield prediction before final harvest.

\section{Materials and Methods}

\section{Study area}

The study area focuses on Thanjavur district which extends over 3,39,657 ha, stands unique from time immemorial for its agricultural activities and is rightly acclaimed as the rice bowl of Tamil Nadu (Fig. 1). It is one of the major districts of the Cauvery Delta region which is referred as the "Granary of South India" due to the high fertility and share of food grains to the state. Thanjavur is located between $10^{0} 8^{\prime}$ to $11^{0} 12^{\prime}$ North latitudes and $78^{\circ} 48^{\prime}$ to $79^{\circ} 38^{\prime}$ East longitudes in Central Tamil Nadu bounded on the east by Nagapattinam and Tiruvarur Districts, on the west by Thiruchirappally and Pudukottai districts, on the south by the Palk straits and Pudukkottai district and on the north by river Kollidam. The economy of Thanjavur district is mainly depended upon agriculture and allied sector. Above $75 \%$ of the workforce have been depending on agriculture for their livelihood. The district is a deltaic plain fed by rivers Cauvery, and Vennar. Some portion is also fed by Grant Anaicut canal. Ground water has been regenerated considerably to advance the cropping season. The mean annual rainfall of the Thanjavur is $938 \mathrm{~mm}$. North-East monsoon is the major rainfall season with a mean seasonal rainfall of $462 \mathrm{~mm}$ which sets in during $3^{\text {rd }}$ week of October and continues till the $4^{\text {th }}$ week of December. Samba (Aug to Jan- Feb) is the major crop-growing season in the district followed by Kuruvai (May- June to August) and Thaladi (Sep- Oct to FebMar). The study was conducted during the Samba season of 2015-16 and 2016-17.

\section{Collection of ground truth}

Paddy plots with sufficiently bigger area were identified at 28 locations (Table 2) in the district and ground truth data was collected from these points during Samba rice season 2015-16 and 2016-17 using Global Positioning System (GPS) as well as camera. In each sample location crop cutting experiments were done in an area of $5 \mathrm{~m} \times 5 \mathrm{~m}$. The weight of grain was originally measured in $\mathrm{kg} / 25 \mathrm{~m}^{2}$ and was converted to unit of $\mathrm{kg} /$ ha.

\section{Modis images}

Among the standard MODIS data products available to the users, the 16 day composite 
MODIS-NDVI (MOD13Q1) was used for the study. The spatial resolution of the MODIS product is $250 \mathrm{~m}$ and a total of 14 scene images (Table 1) were downloaded from http://glovis.usgs.gov. The acquisition and coverage of MODIS NDVI product on Thanjavur district from glovis.usgs.gov.in is presented in Figure 2.

\section{Data analysis}

Data analysis consists of preprocessing images, gathering rice spectral information from the MODIS images, and mathematical analysis. Collecting the MODIS images from the websites, image cropping, and geographic coordinate transformation are several preprocessing procedures that have been done. The NDVI imageries downloaded were preprocessed using (Modis Reprojection Tool) MR $\mathrm{T}$ so as to convert it from Sinusoidal Projection to Universal Transverse Mercator co-ordinate system. The preprocessed images that were in the hierarchical data format (hdf) were converted to "img" format through "Export raster data" provision in ArcGIS. Using the "img" raster, NDVI for each pixel was calculated using Raster calculator in Map Algebra by dividing it with a constant (10000). The ground truth points were superimposed over the NDVI map for further analysis (Fig. 3).

From the output raster NDVI values for 28 locations in Thanjavur district were retrieved using the "Extract multivalues to points" provision in ArcGIS. Then, a relationship between rice age and rice NDVI was performed. Nuarsa and Nishio (2007), suggested that the quadratic equation is the best relationship between rice age and rice NDVI. From the quadratic equation, 3 variables were calculated i.e., maximum NDVI value $\left(\mathrm{NDVI}_{\max }\right)$ attained during crop period, the age of the rice plant when the NDVI peak is achieved (Age NDVImax ), and summation of the rice NDVI during observation $\left(\sum\right.$ NDVI) as illustrated in Figure 4.

If $y=a x^{2}+b x+c$ is the relationship equation of rice age and NDVI where $y$ is the NDVI and $x$ is the rice age, AgeNDVI $I_{\max }$ can be found when $\Delta y / \Delta x$ is equal to 0 . The $x$ value can be calculated with the following equation:

$$
\begin{aligned}
& y=a x^{2}+b x+c \\
& \frac{\Delta y}{\Delta x}=2 a x+b \\
& 0=2 a x+b \\
& x=\frac{-b}{2 a}
\end{aligned}
$$

Where, $y$ is the NDVI, $x$ is the rice age, and $a$, $b, c$ are a coefficient of $x^{2}, x$, and constant value, respectively. The $x$ value obtained from the equation above is the Age $\mathrm{NDVI}_{\max }$. By means of substitution of the $x$ value in equation $y=a x^{2}+b x+c$, the $y$ value when the peak NDVI occurred (NDVI $I_{\max }$ ) can be calculated. The summation of the rice NDVI during observation ( $\Sigma$ NDVI) can be computed using the following equation.

$$
\Sigma N D V I=\int_{A g e 1}^{A g e 2}\left(a x^{2}+b x+c\right) d x
$$

Where, Agel and Age2 are a beginning and endings of the rice plant observation, respectively. Then relationships between Age $\mathrm{NDVI}_{\max }, \mathrm{NDVI}_{\max }$, and $\Sigma \mathrm{NDVI}$ with rice yield was developed. The equation showed the best relationship was selected to estimate the rice yield. The statistical parameters used to evaluate the best relationship is coefficient of determination $\left(\mathrm{R}^{2}\right)$ and a standard error of the estimation (SE) according to the following equations (Sa et al., 2008). Higher value of $\mathrm{R}^{2}$ and lower value of SE shows the better relationship. 


$$
\begin{aligned}
& R^{2}=1-\frac{\sum(y-\overline{\mathrm{y}})^{2}}{\sum\left(y-y^{\prime}\right)^{2}} \\
& \mathrm{SE}=\sqrt{\frac{\sum\left(y-y^{\prime}\right)}{n}}
\end{aligned}
$$

Where,

$\mathrm{R}^{2}=$ coefficient of determination

$\mathrm{SE}=$ standard error of estimation

$\mathrm{y}=$ actual value

$\mathrm{y}^{\prime}=$ predicted value

$\overline{\mathrm{y}}=$ average predicted value

$\mathrm{n}=$ number of sample

\section{Results and Discussion}

Analysis was done on the relationship between age of the rice plant and MODISNDVI for 28 sample points in the district. Out of the 14 temporal images obtained during 2015-16 a few images showed comparatively low values due to cloud interfere. To overcome this the NDVI time series was primarily smoothed by employing standard statistical procedures. Quadratic equations are set between age of the plant and NDVI values obtained from multi temporal MOD13Q1 images in all the locations and are shown in Table 3. Out of the 28 locations under study, in 25 locations the $\mathrm{R}^{2}$ values for these equations showed fairly higher values ranging from 0.724 to 0.968 . The highest $\mathrm{R}^{2}$ value was obtained for the quadratic equation made for Keelakurichi village in Madukkur block and is presented in Figure 5. The Standard Error of estimation (SE) ranged from 0.027 to 0.120 . The high value of $R^{2}$ in majority of the samples indicate that there exists consistent relationship between rice age and NDVI value and the lower values of SE indicate that there are small differences between the actual and estimated values of NDVI. By employing Equation (1), (2) and (3), Age $\mathrm{NDVI}_{\max }$, $\mathrm{NDVI}_{\text {max }}$, and $\Sigma$ NDVI were calculated for the 28 locations under study. The Age $\mathrm{NDVI}_{\max }$ ranged from 38.835 to 108.794 depending upon the varieties and locations. From this it can be inferred that NDVI values increased gradually from the transplanting period onwards and during the third month it reached the maximum and then it decreased. The $\mathrm{NDVI}_{\text {max }}$ ranged from 0.451 to 0.810 and the $\Sigma$ NDVI values fluctuated from 22.835 to 62.877. The values of Age $\mathrm{NDVI}_{\max }$, $\mathrm{NDVI}_{\text {max }}$ and $\Sigma$ NDVI are presented in Table 4.

Relationship was worked out between Age $\mathrm{NDVI}_{\max }, \mathrm{NDVI}_{\max }$, and $\Sigma \mathrm{NDVI}$ with rice productivity and the equation showed an exponential form. The equations were $\mathrm{y}=$ $1890.4 \mathrm{e}^{0.0121 \mathrm{x},} \mathrm{y}=1701.4 \mathrm{e}^{1.5173 \mathrm{x}, \mathrm{y}}=$ $1903.6 \mathrm{e}^{0.0201 \mathrm{x}}$ for yield with Age $\mathrm{NDVI}_{\max }$, $\mathrm{NDVI}_{\max }$ and $\Sigma$ NDVI respectively (Fig. 6, 7 and 8). $\Sigma$ NDVI showed the best relationship with rice productivity with a high $\mathrm{R}^{2}$ value of 0.7495

Quadratic equations were derived between MODIS-NDVI and age of the rice plant during 2016-17. The coefficients of equation, $R^{2}$ value and $S E$ are presented in Table 5. The maximum $\mathrm{R}^{2}$ value of 0.971 and minimum $\mathrm{R}^{2}$ value 0.455 were obtained for the equation generated at Thittai village in Thanjavur block and Perumalkovil village in Pattukkottai block. The $\mathrm{R}^{2}$ values were above 0.7 in 24 locations out of the 28 locations under study. The Standard Error (SE) of the equations were also showed low values (ie. less than 0.07) in all the locations. Age $\mathrm{NDVI}_{\max }, \mathrm{NDVI}_{\max }$, and $\Sigma$ NDVI were calculated for the Samba rice growing season 2016-17 (Table 6). The Age NDVI max $_{\text {and }}$ $\mathrm{NDVI}_{\max }$ ranged from 59.683 to 94.664 and from 0.709 to 0.908 respectively at different locations. $\Sigma$ NDVI varied between 38.687 and 64.043. Rice yield prediction for Samba rice during 2016- 2017 was done based on the relationship between yield and $\Sigma$ NDVI, obtained during 2015-16, i.e., $\mathrm{y}=$ $1903.6 \mathrm{e}^{0.0201 \mathrm{x}}$, where $\mathrm{x}$ is the age at which maximum NDVI is observed (NDVI $\mathrm{max}_{\text {ax }}$ ) and $\mathrm{y}$ is the productivity. 
Table.1 MOD13Q1 NDVI data acquisition schedule

\begin{tabular}{|c|c|c|c|}
\hline \multicolumn{4}{|c|}{ MOD13Q1 NDVI data acquisition } \\
\hline Date & Path & Row & Product \\
\hline $13 / 08 / 2015$ & 25 & 7 & $\mathrm{~A} 2015225 . \mathrm{h} 25 \mathrm{v} 07.005$ \\
\hline $29 / 08 / 2015$ & 25 & 7 & $\mathrm{~A} 2015241 . \mathrm{h} 25 \mathrm{v} 07.005$ \\
\hline $14 / 09 / 2015$ & 25 & 7 & $\mathrm{~A} 2015257 . \mathrm{h} 25 \mathrm{v} 07.005$ \\
\hline $30 / 09 / 2015$ & 25 & 7 & $\mathrm{~A} 2015273 . \mathrm{h} 25 \mathrm{v} 07.005$ \\
\hline $16 / 10 / 2015$ & 25 & 7 & $\mathrm{~A} 2015289 . \mathrm{h} 25 \mathrm{v} 07.005$ \\
\hline $1 / 11 / 2015$ & 25 & 7 & $\mathrm{~A} 2015305 . \mathrm{h} 25 \mathrm{v} 07.005$ \\
\hline $17 / 11 / 2015$ & 25 & 7 & $\mathrm{~A} 2015321 . \mathrm{h} 25 \mathrm{v} 07.005$ \\
\hline $03 / 12 / 2015$ & 25 & 7 & $\mathrm{~A} 2015337 . \mathrm{h} 25 \mathrm{v} 07.005$ \\
\hline $19 / 12 / 2015$ & 25 & 7 & $\mathrm{~A} 2015353 . \mathrm{h} 25 \mathrm{v} 07.005$ \\
\hline $01 / 01 / 2016$ & 25 & 7 & $\mathrm{~A} 2016001 . \mathrm{h} 25 \mathrm{v} 07.005$ \\
\hline $17 / 01 / 2016$ & 25 & 7 & $\mathrm{~A} 2016017 . \mathrm{h} 25 \mathrm{v} 07.005$ \\
\hline $02 / 02 / 2016$ & 25 & 7 & $\mathrm{~A} 2016033 . \mathrm{h} 25 \mathrm{v} 07.005$ \\
\hline $18 / 02 / 2016$ & 25 & 7 & $\mathrm{~A} 2016033 . \mathrm{h} 25 \mathrm{v} 07.005$ \\
\hline $05 / 03 / 2016$ & 25 & 7 & $\mathrm{~A} 2016033 . \mathrm{h} 25 \mathrm{v} 07.005$ \\
\hline
\end{tabular}

Table. 2 Ground truth points in the study area

\begin{tabular}{|c|c|c|c|c|c|c|}
\hline \multirow{3}{*}{$\begin{array}{l}\text { Sample } \\
\text { plots } \\
1 \\
\end{array}$} & \multirow{3}{*}{$\begin{array}{l}\text { Location } \\
\text { Ammankudi }\end{array}$} & \multirow[t]{2}{*}{ Block } & \multicolumn{2}{|c|}{$\begin{array}{l}\text { Geographic co- } \\
\text { ordinates (Degree } \\
\text { decimals) }\end{array}$} & \multicolumn{2}{|c|}{$\begin{array}{l}\text { Rice observation } \\
\text { age }\end{array}$} \\
\hline & & & Lat & Long & Start & End \\
\hline & & Thiruvidaimarudur & 10.950 & 79.499 & 4 & 141 \\
\hline 2 & Kizhamaruthukkudi & Thiruvidaimarudur & 10.999 & 79.491 & 9 & 160 \\
\hline 3 & Thiruvisanallur & Thiruvidaimarudur & 11.008 & 79.421 & 6 & 137 \\
\hline 4 & Kathiramangalam & Thiruppanandal & 11.074 & 79.525 & 8 & 134 \\
\hline 5 & Naikkuppai & Thiruppanandal & 11.143 & 79.537 & 15 & 132 \\
\hline 6 & Pattom & Thiruppanandal & 11.101 & 79.453 & 7 & 150 \\
\hline 7 & Alamamkurichi & Kumbakonam & 11.013 & 79.353 & 13 & 151 \\
\hline 8 & Sakkotttai & Kumbakonam & 10.919 & 79.413 & 4 & 156 \\
\hline 9 & Eraharam & Kumbakonam & 10.998 & 79.359 & 7 & 159 \\
\hline 10 & Rajagiri & Papanasam & 10.913 & 79.252 & 8 & 160 \\
\hline 11 & Perumankudi & Papanasam & 10.909 & 79.272 & 6 & 135 \\
\hline 12 & Sanathi street, & Papanasam & 10.923 & 79.260 & 8 & 159 \\
\hline 13 & Saliyamangalam & Ammapettai & 10.781 & 79.270 & 12 & 139 \\
\hline 14 & Pachakkottai & Ammapettai & 10.793 & 79.281 & 7 & 151 \\
\hline 15 & Kumilakudi & Ammapettai & 10.799 & 79.251 & 8 & 136 \\
\hline 16 & Keelakurichi & Madukkur & 10.548 & 79.403 & 16 & 128 \\
\hline 17 & Ulayakunnam & Madukkur & 10.522 & 79.427 & 14 & 108 \\
\hline 18 & Andani & Madukkur & 10.529 & 79.395 & 4 & 141 \\
\hline 19 & Pannavayal & Pattukkottai & 10.390 & 79.292 & 5 & 138 \\
\hline 20 & Naduvikkottai & Pattukkottai & 10.429 & 79.255 & 12 & 121 \\
\hline 21 & Perumalkovil & Pattukkottai & 10.425 & 79.292 & 12 & 121 \\
\hline 22 & Pulavankadu & Orathanadu & 10.567 & 79.277 & 12 & 105 \\
\hline 23 & Thalayamangalam & Orathanadu & 10.696 & 79.274 & 7 & 125 \\
\hline 24 & Uratchi & Orathanadu & 10.640 & 79.249 & 4 & 122 \\
\hline 25 & Vilangudi & Thiruvaiyaru & 10.909 & 79.107 & 15 & 148 \\
\hline 26 & Maharajapuram, & Thiruvaiyaru & 10.879 & 79.001 & 7 & 138 \\
\hline 27 & Melappunavasal & Thiruvaiyaru & 10.903 & 79.076 & 14 & 148 \\
\hline 28 & Thittai & Thanjavur & 10.839 & 79.175 & 3 & 159 \\
\hline
\end{tabular}


Table.3 Coefficients of quadratic equation for relationship between rice age and NDVI with $\mathrm{R}^{2}$ and Standard Error of Estimation (SE) during 2015- 2016

\begin{tabular}{|c|c|c|c|c|c|}
\hline Sample plots & $\mathrm{a}$ & $\mathrm{b}$ & $\mathrm{c}$ & $\mathrm{R}^{2}$ & SE \\
\hline 1 & -0.00006350 & 0.010 & 0.348 & 0.889 & 0.062 \\
\hline 2 & -0.00006524 & 0.012 & 0.248 & 0.774 & 0.109 \\
\hline 3 & -0.00005515 & 0.012 & 0.136 & 0.739 & 0.120 \\
\hline 4 & -0.00006861 & 0.011 & 0.350 & 0.860 & 0.069 \\
\hline 5 & -0.00006719 & 0.009 & 0.462 & 0.786 & 0.074 \\
\hline 6 & -0.00004917 & 0.007 & 0.476 & 0.841 & 0.051 \\
\hline 7 & -0.00003006 & 0.004 & 0.586 & 0.835 & 0.043 \\
\hline 8 & -0.00004234 & 0.008 & 0.378 & 0.856 & 0.052 \\
\hline 9 & -0.00004992 & 0.008 & 0.489 & 0.918 & 0.042 \\
\hline 10 & -0.00002388 & 0.005 & 0.425 & 0.583 & 0.060 \\
\hline 11 & -0.00004016 & 0.006 & 0.543 & 0.860 & 0.047 \\
\hline 12 & -0.00002296 & 0.004 & 0.471 & 0.677 & 0.049 \\
\hline 13 & -0.00005836 & 0.010 & 0.257 & 0.909 & 0.039 \\
\hline 14 & -0.00006399 & 0.012 & 0.224 & 0.822 & 0.079 \\
\hline 15 & -0.00006446 & 0.011 & 0.306 & 0.784 & 0.088 \\
\hline 16 & -0.00006673 & 0.012 & 0.131 & 0.968 & 0.028 \\
\hline 17 & -0.00004272 & 0.007 & 0.494 & 0.782 & 0.053 \\
\hline 18 & -0.00003971 & 0.007 & 0.324 & 0.832 & 0.031 \\
\hline 19 & -0.00002575 & 0.002 & 0.577 & 0.739 & 0.046 \\
\hline 20 & -0.00006810 & 0.008 & 0.531 & 0.724 & 0.079 \\
\hline 21 & -0.00004614 & 0.009 & 0.320 & 0.897 & 0.041 \\
\hline 22 & -0.00007185 & 0.010 & 0.335 & 0.870 & 0.050 \\
\hline 23 & -0.00006481 & 0.008 & 0.446 & 0.780 & 0.062 \\
\hline 24 & -0.00001793 & 0.003 & 0.509 & 0.760 & 0.027 \\
\hline 25 & -0.00004649 & 0.009 & 0.363 & 0.730 & 0.083 \\
\hline 26 & -0.00004382 & 0.006 & 0.246 & 0.857 & 0.067 \\
\hline 27 & -0.00003845 & 0.005 & 0.432 & 0.853 & 0.033 \\
\hline 28 & -0.00003159 & 0.006 & 0.416 & 0.656 & 0.073 \\
\hline
\end{tabular}


Table.4 Age NDVI max $_{\text {NDVI }}, \mathrm{NDx}_{\max }, \Sigma \mathrm{NDVI}$ and productivity of rice in sample plots during 2015-2016

\begin{tabular}{|c|c|c|c|c|}
\hline Sample plots & Age NDVI max & NDVI max & $\Sigma$ NDVI(final) & Yield $\mathrm{kg} \mathrm{ha}^{-1}$ \\
\hline 1 & 78.740 & 0.742 & 47.715 & 4952 \\
\hline 2 & 91.968 & 0.800 & 56.387 & 5422 \\
\hline 3 & 108.794 & 0.789 & 61.999 & 5677 \\
\hline 4 & 80.163 & 0.791 & 51.264 & 6500 \\
\hline 5 & 66.974 & 0.763 & 43.932 & 4550 \\
\hline 6 & 71.182 & 0.725 & 45.226 & 4350 \\
\hline 7 & 66.534 & 0.719 & 44.303 & 4550 \\
\hline 8 & 94.473 & 0.756 & 59.129 & 6070 \\
\hline 9 & 80.128 & 0.810 & 55.811 & 5360 \\
\hline 10 & 104.690 & 0.687 & 62.333 & 6675 \\
\hline 11 & 74.701 & 0.767 & 51.177 & 5625 \\
\hline 12 & 87.108 & 0.645 & 50.672 & 5535 \\
\hline 13 & 85.675 & 0.685 & 46.224 & 4760 \\
\hline 14 & 93.765 & 0.787 & 55.941 & 5125 \\
\hline 15 & 85.324 & 0.775 & 52.492 & 5115 \\
\hline 16 & 89.915 & 0.670 & 43.980 & 4650 \\
\hline 17 & 81.929 & 0.781 & 55.637 & 5890 \\
\hline 18 & 88.139 & 0.632 & 46.356 & 5575 \\
\hline 19 & 38.835 & 0.616 & 22.835 & 2325 \\
\hline 20 & 58.737 & 0.766 & 39.855 & 3580 \\
\hline 21 & 97.529 & 0.759 & 59.421 & 6050 \\
\hline 22 & 69.589 & 0.683 & 39.115 & 4690 \\
\hline 23 & 61.719 & 0.693 & 37.235 & 4650 \\
\hline 24 & 83.659 & 0.634 & 49.071 & 5580 \\
\hline 25 & 96.795 & 0.799 & 62.877 & 6505 \\
\hline 26 & 68.462 & 0.451 & 25.967 & 2870 \\
\hline 27 & 65.020 & 0.595 & 34.700 & 5100 \\
\hline 28 & 94.967 & 0.701 & 57.125 & 6750 \\
\hline
\end{tabular}


Table.5 Coefficients of quadratic equation for relationship between rice age and NDVI with $\mathrm{R}^{2}$ and Standard Error of Estimation (SE) for 2016- 2017

\begin{tabular}{|c|c|c|c|c|c|}
\hline Sample plots & $\mathbf{a}$ & $\mathbf{b}$ & $\mathbf{c}$ & $\mathbf{R}^{\mathbf{2}}$ & $\mathbf{S E}$ \\
\hline 1 & -0.00006560 & 0.009 & 0.500 & 0.885 & 0.0517 \\
\hline 2 & -0.00008370 & 0.014 & 0.221 & 0.837 & 0.0663 \\
\hline 3 & -0.00005810 & 0.011 & 0.333 & 0.772 & 0.0464 \\
\hline 4 & -0.00007714 & 0.011 & 0.372 & 0.805 & 0.0564 \\
\hline 5 & -0.00008194 & 0.011 & 0.486 & 0.756 & 0.0557 \\
\hline 6 & -0.00005497 & 0.008 & 0.450 & 0.884 & 0.0368 \\
\hline 7 & -0.00003351 & 0.004 & 0.699 & 0.927 & 0.0373 \\
\hline 8 & -0.00004318 & 0.007 & 0.454 & 0.764 & 0.0399 \\
\hline 9 & -0.00007477 & 0.011 & 0.379 & 0.899 & 0.0582 \\
\hline 10 & -0.00006848 & 0.011 & 0.466 & 0.913 & 0.0588 \\
\hline 11 & -0.00003904 & 0.006 & 0.491 & 0.685 & 0.0395 \\
\hline 12 & -0.00002245 & 0.003 & 0.623 & 0.809 & 0.0241 \\
\hline 13 & -0.00007016 & 0.011 & 0.326 & 0.926 & 0.0428 \\
\hline 14 & -0.00006881 & 0.010 & 0.407 & 0.859 & 0.0593 \\
\hline 15 & -0.00006608 & 0.009 & 0.474 & 0.806 & 0.0483 \\
\hline 16 & -0.00007547 & 0.011 & 0.402 & 0.523 & 0.0443 \\
\hline 17 & -0.00006394 & 0.008 & 0.459 & 0.760 & 0.0364 \\
\hline 18 & -0.00007501 & 0.013 & 0.167 & 0.821 & 0.0415 \\
\hline 19 & -0.00006463 & 0.011 & 0.265 & 0.721 & 0.0499 \\
\hline 20 & -0.00005130 & 0.008 & 0.468 & 0.759 & 0.0353 \\
\hline 21 & -0.00007898 & 0.013 & 0.230 & 0.971 & 0.0502 \\
\hline 22 & -0.00008720 & 0.011 & 0.454 & 0.769 & 0.0585 \\
\hline 23 & -0.00009880 & 0.015 & 0.212 & 0.782 & 0.0591 \\
\hline 24 & -0.00008369 & 0.011 & 0.432 & 0.746 & 0.0591 \\
\hline 25 & -0.00005939 & 0.011 & 0.258 & 0.705 & 0.0436 \\
\hline 26 & -0.00006506 & 0.010 & 0.383 & 0.890 & 0.0513 \\
\hline 27 & -0.00003286 & 0.006 & 0.460 & 0.696 & 0.0269 \\
\hline 28 & -0.00002849 & 0.005 & 0.505 & 0.455 & 0.0368 \\
\hline
\end{tabular}


Table.6 Age NDVI $I_{\max }, \mathrm{NDVI}_{\max }, \Sigma \mathrm{NDVI}$ and productivity of rice in sample plots during 2016-2017

\begin{tabular}{|c|c|c|c|c|}
\hline Sample plots & Age NDVI max & NDVI max & ENDVI & Yield \\
\hline 1 & 68.598 & 0.809 & 47.911 & 4987 \\
\hline 2 & 83.632 & 0.806 & 50.895 & 5295 \\
\hline 3 & 94.664 & 0.854 & 64.043 & 6896 \\
\hline 4 & 71.299 & 0.764 & 44.785 & 4683 \\
\hline 5 & 67.122 & 0.855 & 48.650 & 5061 \\
\hline 6 & 72.767 & 0.741 & 46.411 & 4839 \\
\hline 7 & 59.684 & 0.818 & 45.767 & 4776 \\
\hline 8 & 81.056 & 0.738 & 51.672 & 5378 \\
\hline 9 & 73.559 & 0.784 & 47.334 & 4929 \\
\hline 10 & 80.315 & 0.908 & 60.608 & 6436 \\
\hline 11 & 76.844 & 0.722 & 49.047 & 5102 \\
\hline 12 & 66.815 & 0.723 & 45.466 & 4747 \\
\hline 13 & 78.392 & 0.757 & 47.757 & 4971 \\
\hline 14 & 72.664 & 0.770 & 46.762 & 4873 \\
\hline 15 & 68.099 & 0.780 & 45.713 & 4771 \\
\hline 16 & 72.877 & 0.803 & 48.363 & 5032 \\
\hline 17 & 62.559 & 0.709 & 38.688 & 4143 \\
\hline 18 & 86.655 & 0.730 & 46.837 & 4880 \\
\hline 19 & 85.099 & 0.733 & 48.834 & 5080 \\
\hline 20 & 77.973 & 0.780 & 52.232 & 5439 \\
\hline 21 & 82.299 & 0.765 & 48.043 & 5000 \\
\hline 22 & 63.073 & 0.801 & 42.763 & 4496 \\
\hline 23 & 75.911 & 0.781 & 44.686 & 4674 \\
\hline 24 & 65.719 & 0.793 & 43.789 & 4590 \\
\hline 25 & 92.608 & 0.767 & 55.076 & 5759 \\
\hline 26 & 76.852 & 0.767 & 48.734 & 5070 \\
\hline 27 & 91.296 & 0.734 & 58.203 & 6133 \\
\hline 28 & 87.750 & 0.724 & 56.640 & 5943 \\
\hline
\end{tabular}


Table.7 Verification of predicted Rabi rice yield during 2016-17

\begin{tabular}{|l|c|c|c|}
\hline Blocks & $\begin{array}{c}\text { Actual Yield } \\
\mathrm{kg} \mathrm{ha}^{-1}\end{array}$ & $\begin{array}{c}\text { Predicted } \\
\text { Yield kg ha }^{-1}\end{array}$ & $\begin{array}{c}\text { PBIAS } \\
(\%)\end{array}$ \\
\hline Thiruvidaimarudur & 5351 & 5726 & 7.01 \\
\hline Thiruppanandal & 4912 & 4861 & -1.03 \\
\hline Kumbhakonam & 5177 & 5028 & -2.87 \\
\hline Papanasam & 4815 & 5429 & 12.75 \\
\hline Ammapettai & 4645 & 4872 & 4.88 \\
\hline Madukkur & 4658 & 4685 & 0.59 \\
\hline Pattukkottai & 4458 & 5173 & 16.03 \\
\hline Orathanadu & 4043 & 4587 & 13.44 \\
\hline Thiruvaiyaru & 5100 & 5654 & 10.86 \\
\hline Thanjavur & 4900 & 5943 & 21.28 \\
\hline Mean & 4805 & 5195 & \\
\hline
\end{tabular}

Fig.1 Location map of the study area

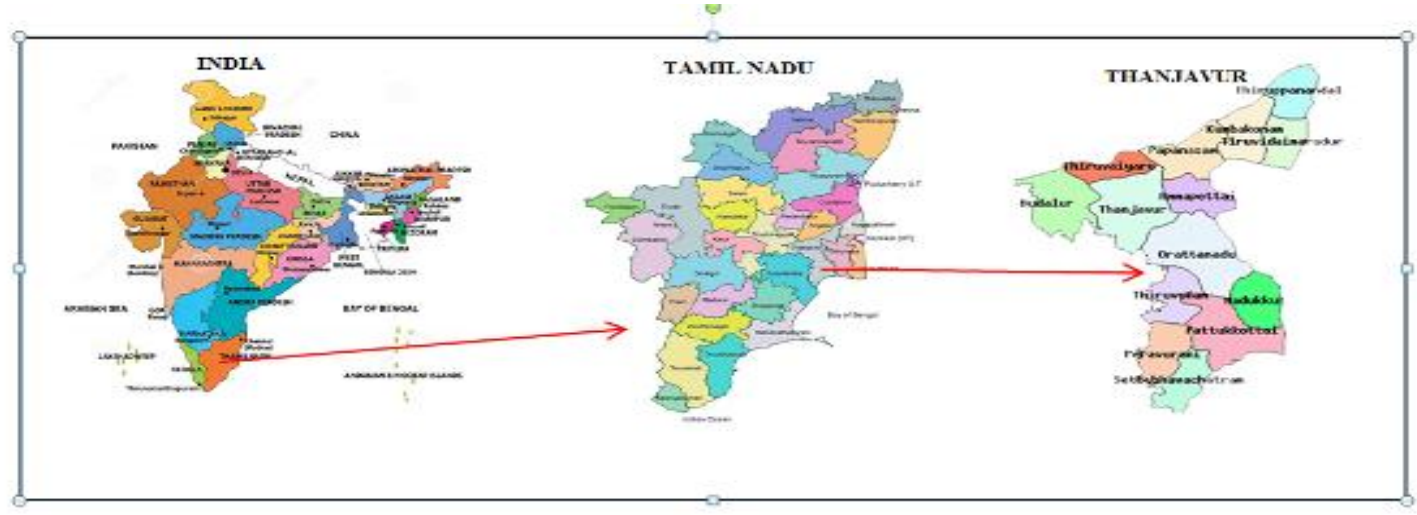

Fig.2 MOD13Q1 NDVI acquisition and coverage on Thanjavur district from glovis.usgs.gov.in

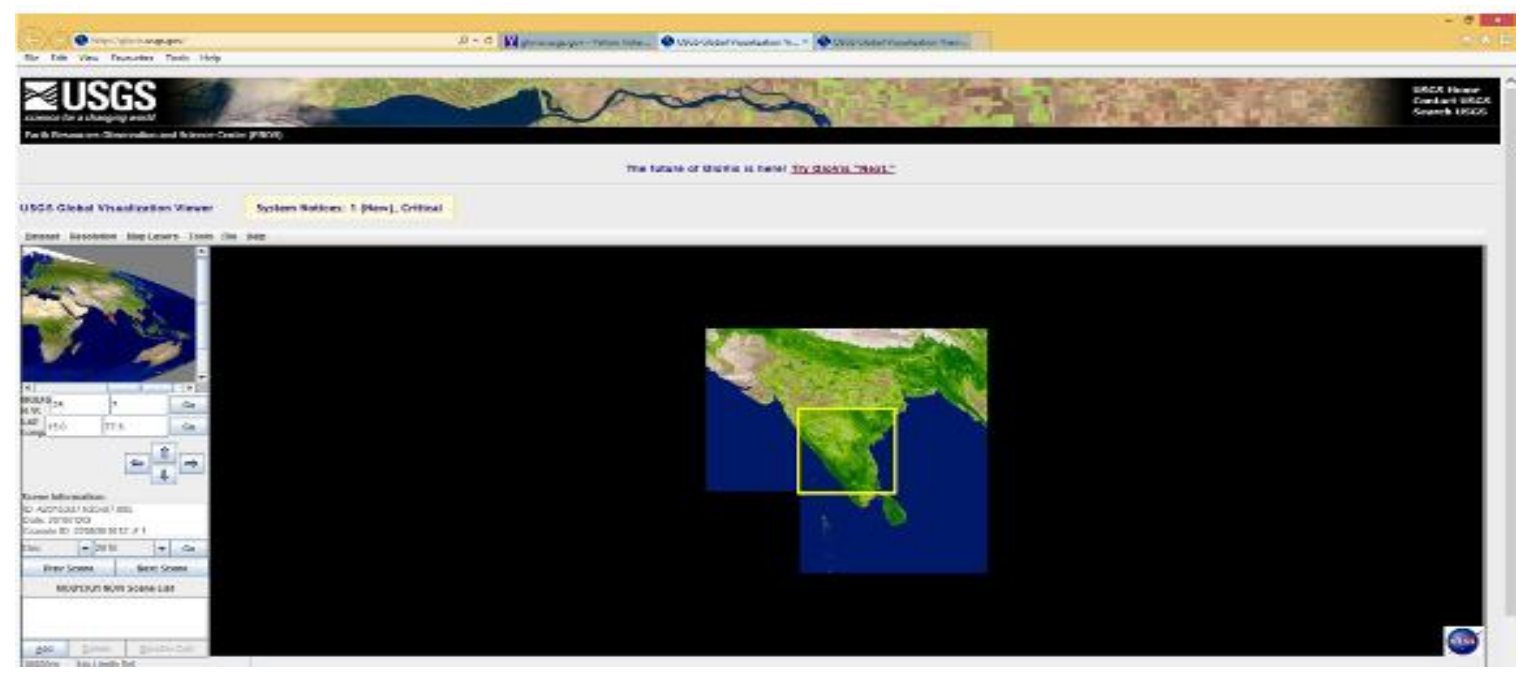


Fig.3 Ground truth points superimposed on NDVI Map

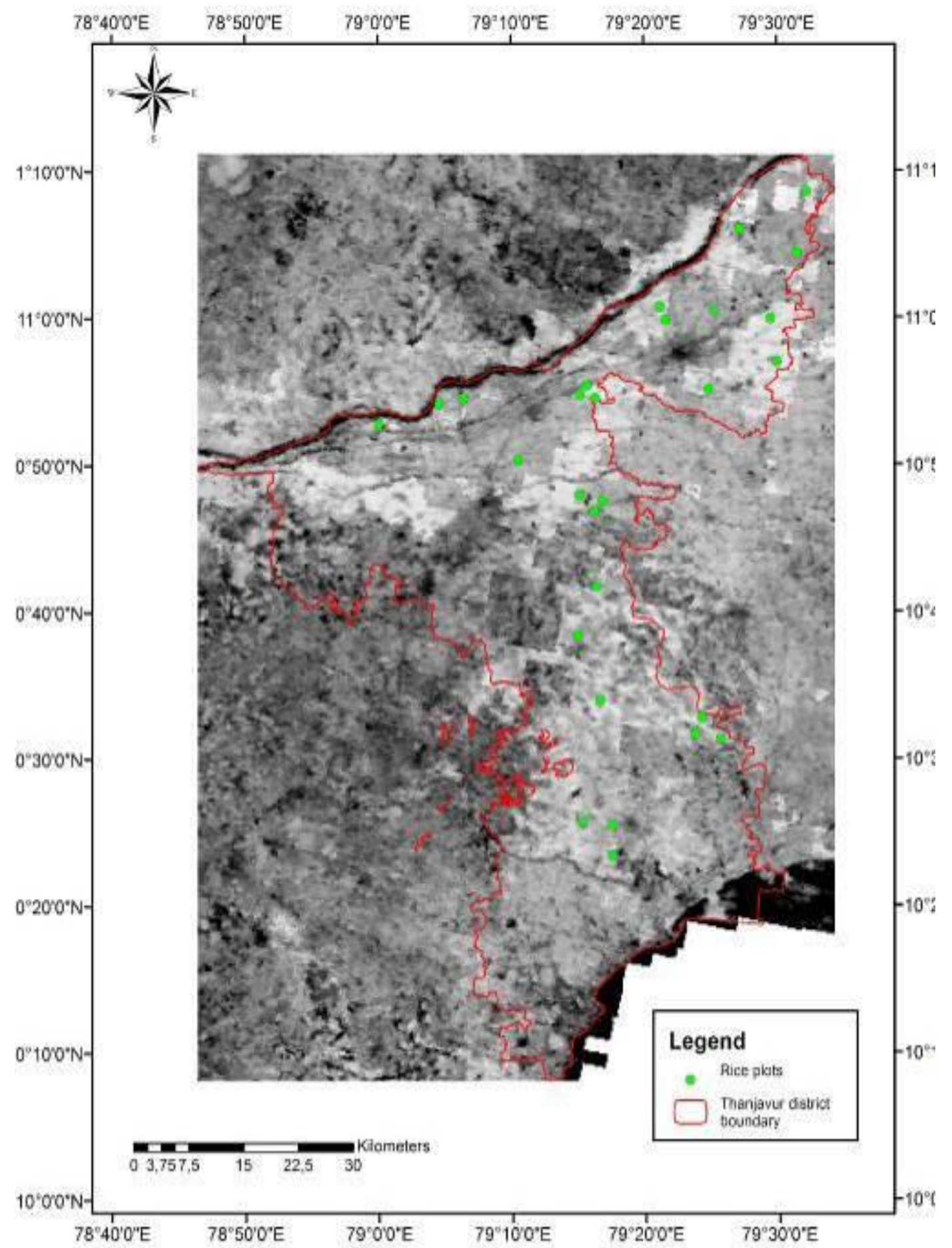


Fig.4 An illustration of method used to calculate AgeNDVI $I_{\max }, \mathrm{NDVI}_{\max }$, and $\Sigma$ NDVI (Nuarsa and Nishio, 2007)

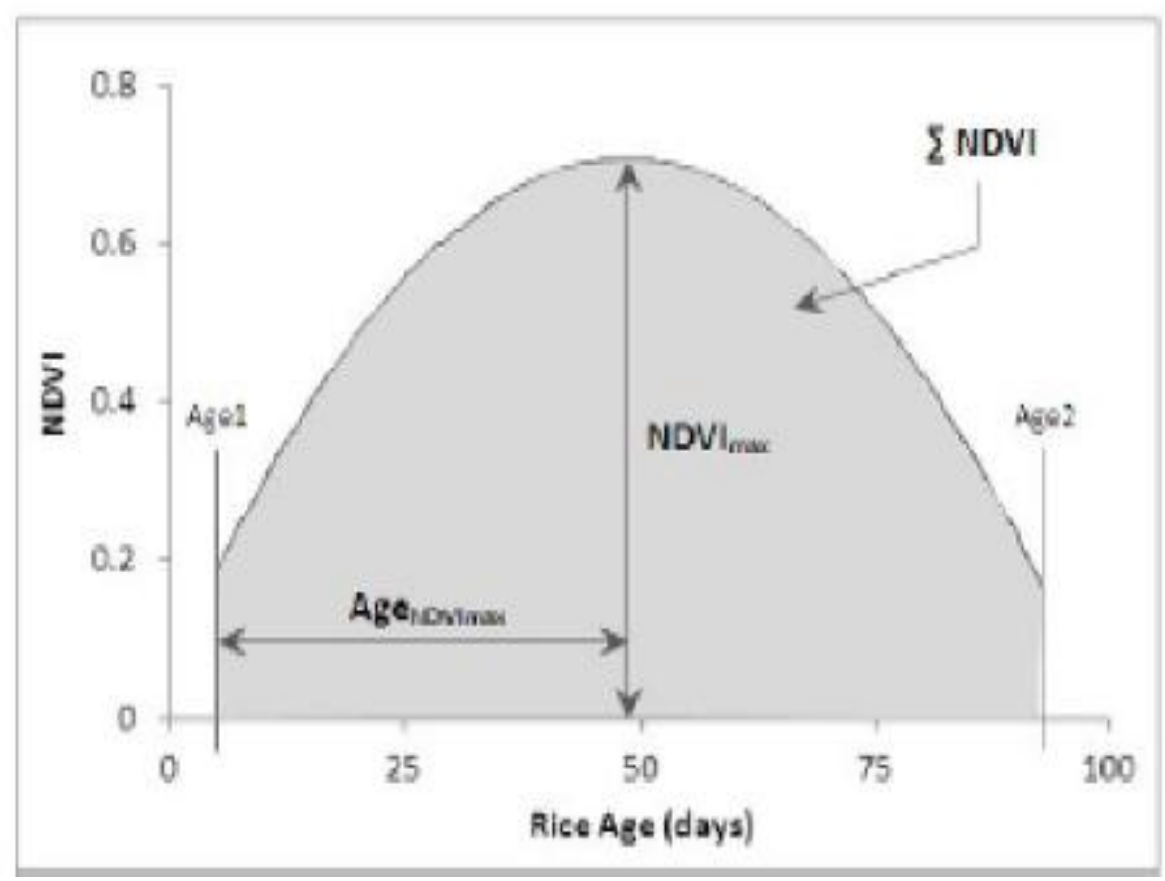

Fig.5 Relationship between maximum NDVI and the rice yield

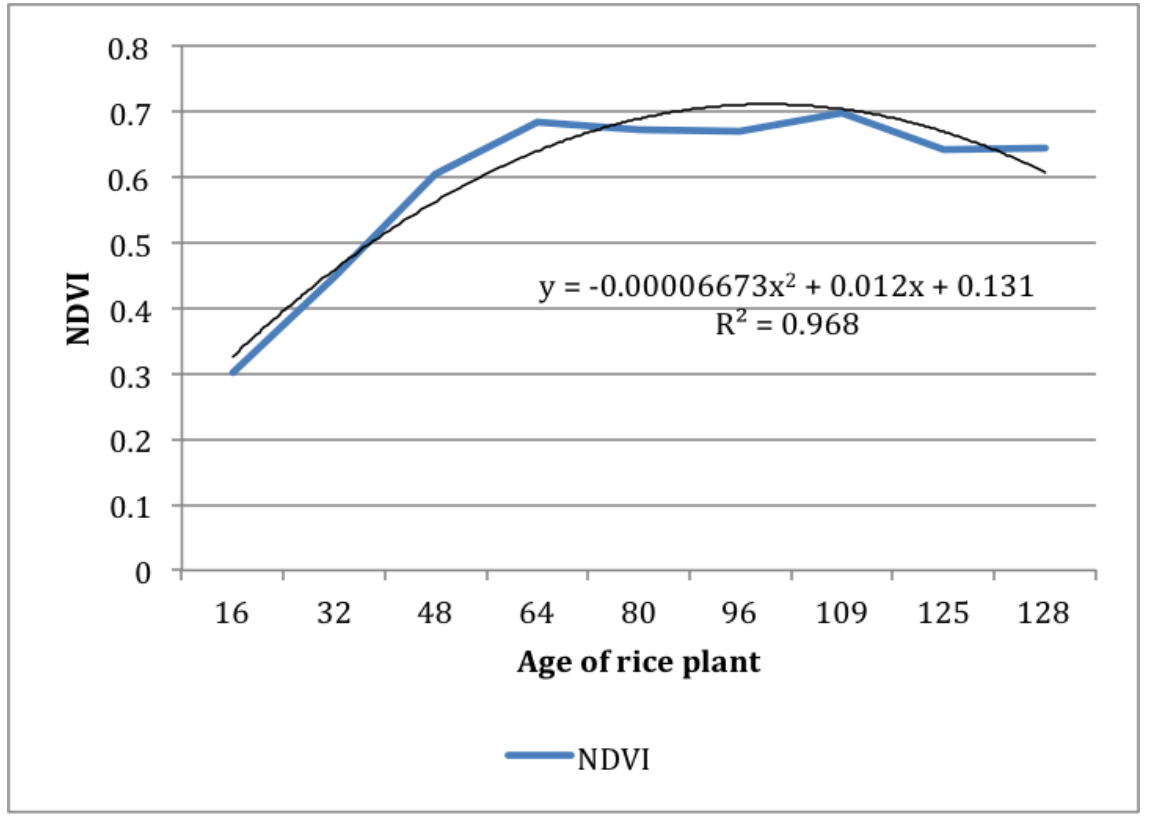


Fig.6 Verification of rice yield prediction using remote sensing

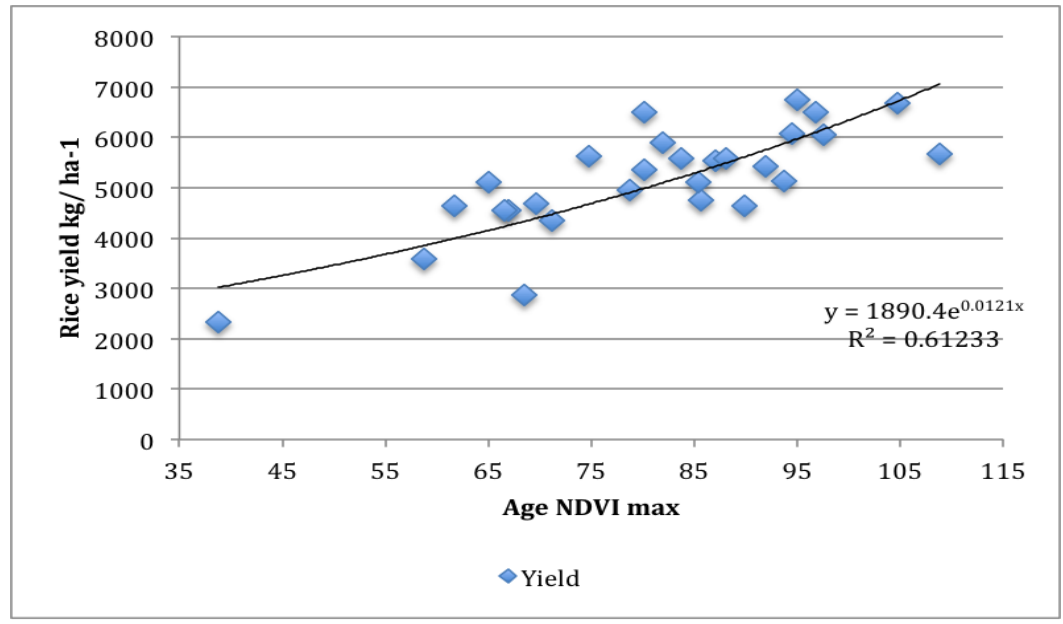

Fig.7 Relationship between maximum NDVI and the rice yield

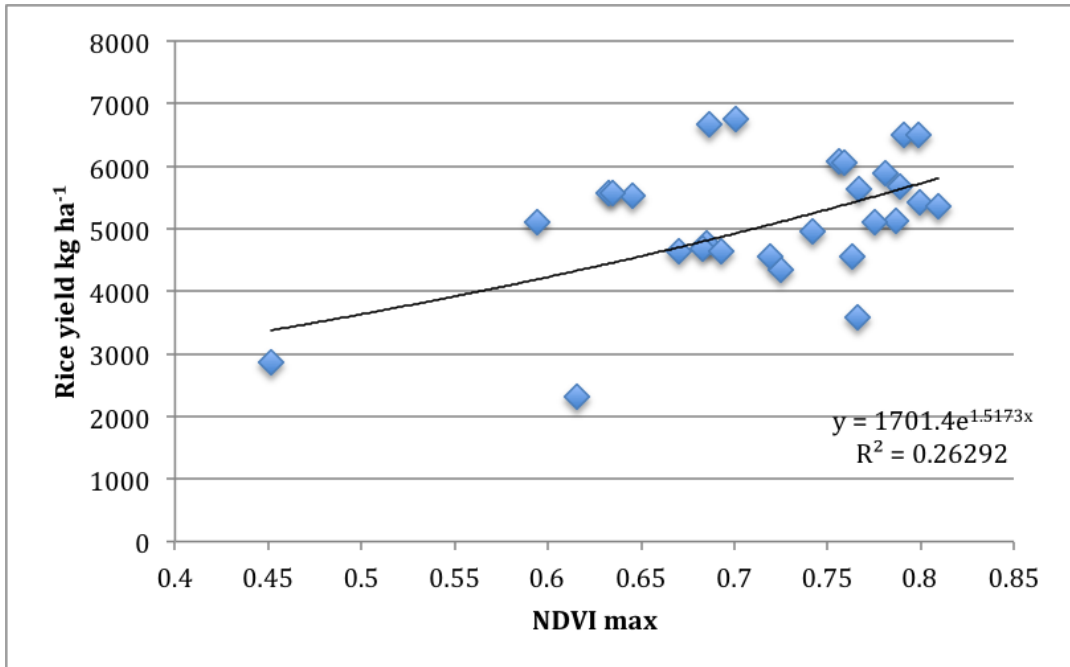

Fig.8 Relationship between $\Sigma$ NDVI and rice productivity

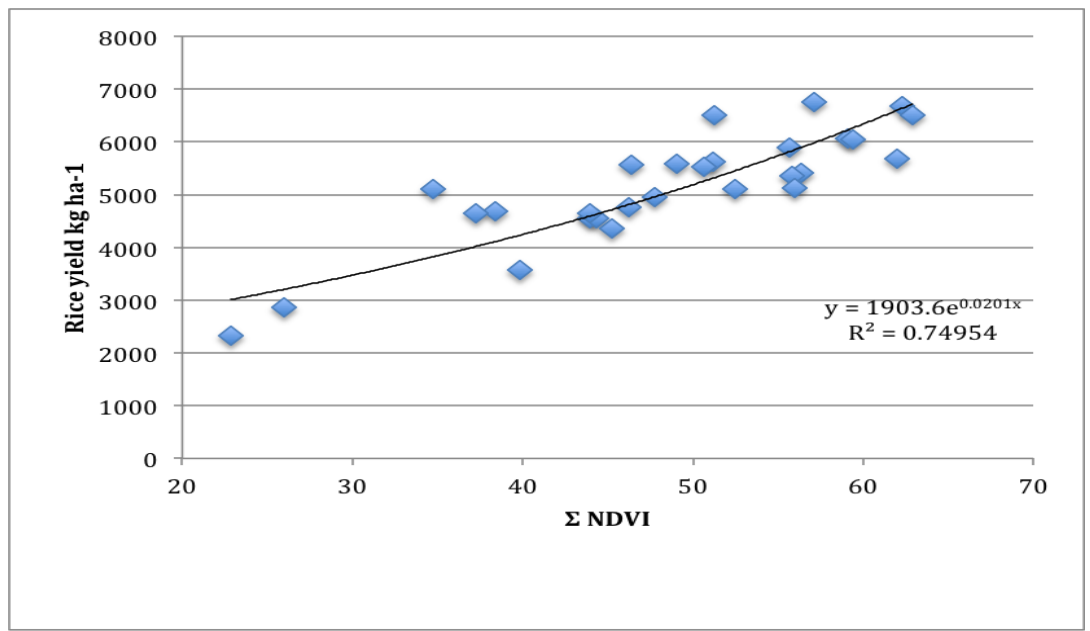


Fig.9 Verification of rice yield prediction using remote sensing

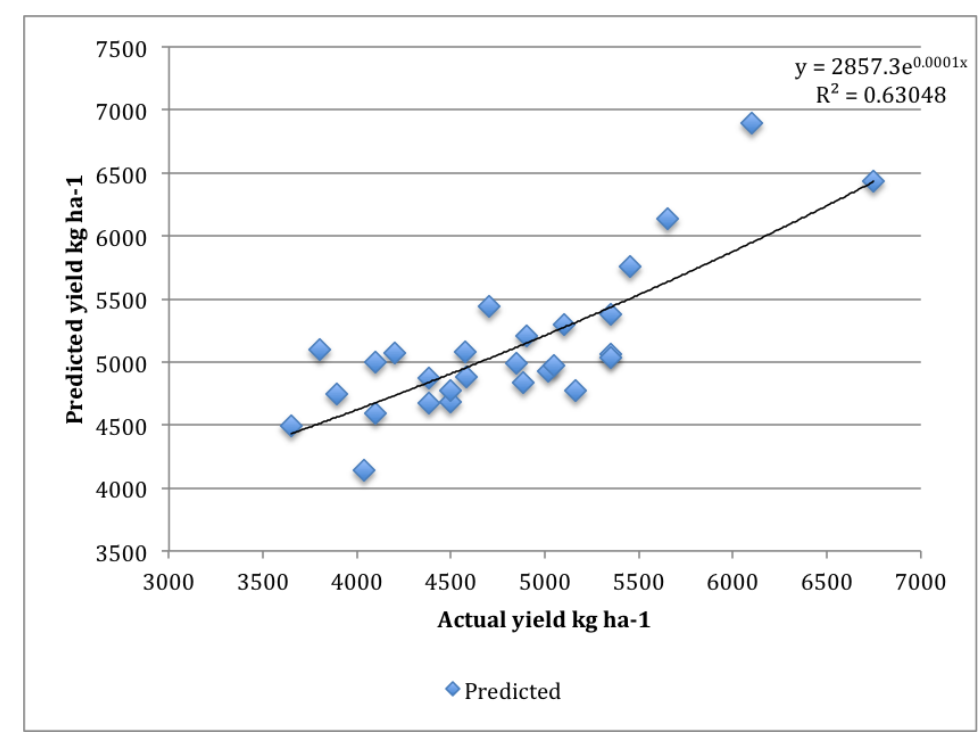

The predicted yield at different locations were averaged blockwise to get the block level productivity and is presented in Table 7 . The predicted yield ranged from $4587 \mathrm{~kg} \mathrm{ha}^{-1}$ to $5943 \mathrm{~kg} \mathrm{ha}^{-1}$ during 2016-17 with an average of $5195.8 \mathrm{ha}^{-1 .}$ Among the blocks Thanjavur showed maximum yield $\left(5943 \mathrm{ha}^{-1}\right)$ followed by Thiruvaiyaru $\left(5654 \mathrm{ha}^{-1}\right)$. At the same time minimum yield was predicted for Orathanadu block $\left(4587 \mathrm{ha}^{-1}\right)$.

The predicted Samba rice yield during 201617 was compared with the actual yields obtained through crop cutting experiments and it deviated both negatively and positively. Per cent BIAS (PBIAS) values ranged from 2.87 to 15.42 . Out of the ten blocks under study 5 blocks had PBIAS values less than \pm 10 which indicated the good agreement between actual and predicted yield. In rest of the districts the PBIAS values ranged from 10.86 to 21.28 per cent and Figure 6 shows a scatter plot comparing actual and predicted rice yields in various sample plots across the district. The relationship between the actual and the predicted values were fairly good with a $R^{2}$ value of 0.6305 . Even though accuracy is not very high, these kinds of relationship can be used as reliable method for estimating rice yield even one month before harvesting. Usually, conventional method will take from few months to few years to produce aggregated rice production statistics.

NDVI is one of the prominent factors indicating the vegetation growth condition and the degree of vegetation cover of an area and it has obvious seasonal variations (Zhao, et al., 2004). In the study multi temporal values of MODIS-NDVI (MOD13Q1) plotted against age of the rice plant showed a definite pattern, which comply with the rice crop growing season in Thanjavur district. A gradual increase in the NDVI was observed with increase in age of the rice plant, attains a peak value and then declines (Fig. 5) Higher value of NDVI means higher the (Near Infrared) NIR component of the reflected radiation and is directly related to the greenness (Niel and McVicar, 2001). More greenness of the plant means higher the chlorophyll content and greater is the potential of rice plant to give higher yields. This study demonstrates a strong relationship between $\Sigma$ MODIS-NDVI (MOD13Q1) and rice yield $\left(\mathrm{R}^{2}=0.7495\right)$. Nuarsa et al., 2011 also described similar results. Harrison et al., (1984) and Rasmussen (1992) reported a 
positive correlation between $\Sigma$ NDVI with the rice yield using Landsat MSS and NOAA AVHRR respectively. The PBIAS between the predicted yield showed a variation of less than \pm 10 per cent in 5 out of the 10 districts under study. This disagreements between the actual and predicted rice yield estimates could be attributed by other factors, such as atmospheric interference such as cloud (Mkhabela et al., 2011), micro level weather variation and water availability (Son et al., 2013) and uncertaininty associated with ground based estimates (Mosleh and Hassan, 2014).

The results obtained by this research confirm that there is an observable relationship with rice yield and NDVI. A rice yield prediction model was developed based on MODISNDVI (MOD13Q1) 16 day composite at a spatial resolution of $250 \mathrm{~m}$ obtained during 2015-16. Further the model was employed for rice yield prediction during Samba 2016-17. The PBIAS between actual and predicted yield showed less than \pm 10 per cent in 5 out of 10 districts under study. Samba season of Tamil Nadu coincides with North east monsoon season and the clouds during the season often cause interference to optical satellite images. Since MODIS-NDVI (MOD13q1) products are continuously available at an interval of 16 days, the underestimation of NDVI values if any can be corrected using adjacent scenes in the time series. In India, the efficiency of crop yield estimation has been found to improve substantially after combining satellite spectral data with survey data based on crop cutting experiments (Li, 2000). MODIS products have no cost and are available to the user community in the web. The study shows that yield prediction using MODIS-NDVI (MOD13Q1) is a fast and inexpensive way and could be considered as a promising method for rice yield prediction.

\section{References}

Banair, A.1995. A review of vegetation indices. Remote Sens. 13: 95-120.

Basso, B., Cammarano, D. and Carfagna, E. 2013.Review of crop yield forecasting methods and early warning systems. Proceedings of the First Meeting of the Scientific Advisory Committee of the Global Strategy to Improve Agricultural and Rural Statistics, FAO Headquarters, Rome, Italy, 18-19 July.

Bastiaanssen, W.G.M. and Ali, S., 2003. A new crop yield forecasting model based on satellite measurements applied across the Indus Basin Pakistan. Agric. Ecosystem and Environment. 94:321- 340 .

Becker-Reshef, I., Vermote, E., Lindeman, M. and Justice, C., 2010. A generalized regressionbased model for forecasting winter wheat yields in Kansas and Ukraine using MODIS data. Remote Sens. Environ. 114:1312-1323.

Dadhwal V. K. and Ray S. S. 2000. Crop assessment using remote sensing - Part II: Crop condition and yield assessment. Indian J. of Agric. Economics, 55(2): 54-67.

Harrison, B.A., Jupp, D.L.B., Ibrahim, A.A. and Angus, J.F. 1984. The use of Landsat data for monitoring growth of irrigated crops. Proeedings of Third Australasian Remote Sensing Conference, 21-25 May 1984, Queensland, Australia, 36-43.

IGOL. 2006. Agricultural Monitoring Meeting convened for Integrated Global Observations for Land, Rome.

Kouadio, L., Newlands, N. K., Davidson, A., Zhang Y. and Chipanshi, A. 2014. Assessing the Performance of MODIS NDVI and EVI for seasonal crop yield forecasting at the eco district scale. Agric. For. Meteorol. 173: 7484

Lane, D., Lu, J., Peres, C. and Zitek, E. 2008. Online Statistics: An Interactive Multimedia Course of Study. Available from: URL:http://onlinestatbook.com/ index.html

Li, B. 2000. Correlation between AVHRR NDVI and climate factors, Acta Ecologica Sinica, 20 (5): 898-902

Lopresti, M. F., Di Bella, C. M., Degioanni, A. J. 2015. Relationship between MODIS-NDVI data and wheat yield: A case study in Northern Buenos Aires province, Argentina, 
Information processing in Agriculture. 2: 7384

Mahboob, M. G., Islam, A. T. and Deshapriya, L. 2016. Rice mapping and monitoring in Sylhet region of Bangladesh using MODIS NDVI. Proceedings of Asia Flux Mini-Workshop on Remote sensing and ecological / environmental monitoring, March 2016, Thailand, 26-30.

Misra, S.R. and Shrivastava, A.K. (1998). Sugarcane research in the Post-Independence era. Indian J. of Agric. Sci. 68 : 465-473.

Mkhabela, M.S., Bullock P., Raj S., Wang S., Yang Y. 2011. Crop yield forecasting on the Canadian prairies using MODIS NDVI data. Agric. For. Meteo. 151(3): 385-393.

Mosleh, M.K., Hassan, Q.K., 2014. Development of a remote sensing-based "Boro" rice mapping system. Remote Sens. 6(3): 1938-1953.

Mostafa, K. K. M. 2015. Use of GIS and Remote sensing in mapping rice areas and forecasting it's production at large geographical extent. $\mathrm{Ph}$. D. thesis. University of Calgary, Albaerta, Canada.

Narasimhan, R. L., Chandra, H., 2000. Application of remote sensing in agricultural statistics. Indian Journal of Agricultural Economic, 55(2):120-124.

Niel, T.G.V., and McVicar, T.R. 2001. Remote Sensing of Rice-Based Irrigated Agriculture: A Review. Rice CRC Technical Report, 1101-05.

Noureldin, N.A., Aboelghar, M.A.,Saudy, H.S., Ali, A.M. 2013. Rice yield forecasting models using satellite imagery in Egypt. Egypt. J. Remote Sens. Space Sci., 16:125-131.

Nuarsa, I.W., Nishio, F. and Hongo, C. 2011. Rice yield estimation using Modis data. Proceeding of the $2^{\text {nd }}$ Cresos International Symposium on South East Asia Environmental Problems and Satellite Remote
Sensing, Denpasar, Bali-Indonesia, $21-22$ February 2011, 121-126

Nuarsa, I.W., and F. Nishio. 2007. Relationships between rice growth parameters and remote sensing data. J. of Remote Sens. and Earth Sciences. 4: 102-112.

Prasad A. K., Chai, L., and Singh, R. P. 2006. Crop yield estimation model for Iowa using remote sensing and surface parameters. Int. J. Appl. Earth Obs. Geoinf. 8(1): 26-33.

Rasmussen, M.S. 1992. Assessment of millet yields and production in northern Burkina Faso using integrated NDVI from AVHRR. Int. J. Remote Sens. 13: 3431-3442.

Reynolds, C.A., Yitayew, M., Slack, D.C., Hutchinson, C.F., Huete, A., Petersen, M.S., 2000. Estimating crop yields and production by integrating the FAO crop specific water balance model with real- time satellite data and ground-based ancillary data. Int. $J$. Remote Sens. 21:3487-3508.

Shresthan, R.P. and Naikaset, S. 2003. Agro-spectral models for estimating dry season rice yield in the Bangkok Plain of Thailand. Asian J. Geoinf. 4:11-19.

Son, N. T., Chen, C. F., Chen, C.R., Chang, L.Y., Duc, H.N., Nguyen, L.D., 2013. Prediction of rice crop yield using MODIS EVI-LAI -data in the Mekong Delta, Vietnam. Int. J. Remote Sens. 34(20): 7275-7292.

Wang, Y.P., Chang, K.W., Chen, R.K., LO, J.C. and Shen, Y. 2010. Large-area rice yield forecasting using satellite imageries. Int. J. Appl. Earth Obs. Geoinf. 12: 27-35.

Zhao, B., Liu, C. and Wang, J. 2004. Spatial and temporal change of MODIS-NDVI in Xilinguole Grassland. Grassland of China. 26(1): $1-8$

Zhao, Y., 2001. Principles and Methods of Remote Sensing Application Analysis, Publishing House of Science, Beijing.

\section{How to cite this article:}

Ajith, K., V. Geethalakshmi, K.P. Ragunath, S. Pazhanivelan and Dheebakaran Ga. 2017. Rice Yield Prediction Using MODIS - NDVI (MOD13Q1) and Land Based Observations. Int.J.Curr.Microbiol.App.Sci. 6(12): 2277-2293. doi: https://doi.org/10.20546/ijcmas.2017.612.263 